\title{
LA LIBRERÍA DE CISNEROS EN LA CATEDRAL DE TOLEDO SEGÚN LOS TEXTOS DE GÓMEZ DE CASTRO (1569) Y QUINTANILLA (1653): HIPÓTESIS SOBRE SU TRAZA Y PROGRAMA ICONOGRÁFICO
}

\author{
POR \\ ISABEL MATEO GÓMEZ \\ Departamento de Arte del C.S.I.C.
}

\begin{abstract}
Basándonos en las biografías más próximas a Cisneros hemos hallado datos suficientes para poder deducir, que el proyecto pictórico de las «Librería» pudo deberse a Pedro Berruguete, desarrollando en ella un programa pictórico muy similar al del Studiolo de Urbino, representando en él a los «hombres sabios» del cristianismo.

Palabras clave: Cisneros - Librería - Catedral - Toledo - Berruguete - Borgoña.

Through the study of biographies of Cisneros, sufficient data has been encountered to be able to propose that the pictorial project to decorate his Library in Toledo Cathedral could be the work of Pedro Berruguete, who developed a program very similar to that of the Studiolo of Urbino, but representing the «wise men» of Christianity.

Key words: Cisneros - Library - Cathedral - Toledo - Berruguete - Juan de Borgoña.
\end{abstract}

En el año 1495 Cisneros es nombrado Arzobispo de Toledo al fallecer el cardenal Mendoza. Durante su mandato Cisneros lleva a cabo muchas obras de orden artístico, tanto en Toledo como en Alcalá de Henares, pero es la obra de la desaparecida «Librería» de la catedral toledana a la que vamos a dedicar este trabajo.

Los documentos referentes a ella, publicados por Zarco y Pérez Sedano, datan del 16 de febrero de 1516 y en ellos se dice que se le encarga a Juan de Borgoña la pintura mural de la biblioteca «conforme a las condiciones que hizo Pedro de Gumiel», terminándosele de pagar, por la pintura «al fresco de la biblioteca o librería de esta santa Iglesia», el 22 de octubre de 1519, 22.625 maravedies de los 100.000 maravedies en que tasó la obra Antonio de Comontes, por parte de la catedral y Juan de Villoldo, por parte del pintor ${ }^{1}$.

Al haber desaparecido la obra pictórica, los autores que han escrito sobre Borgoña, la suponen similar a la que éste realizó con anterioridad en la Sala Capitular de la catedral, por la que cobra 165.000 maravedies. Angulo las enjuicia como importantes, subrayando el alto

${ }^{\prime}$ Datos documentales para el estudio del arte español. Madrid, 1914-16, pp. 44 (I) y 42 (II).

$A E A$, LXXVI, 2003, 301, pp. 5 a 21 
coste de la «librería», y lamentando su desaparición. Camón hace los mismos comentarios que Angulo pero precisa la importancia que debieron tener los frescos de la librería, por lo que tardaron en pintarse - tres años- y por el precio ${ }^{2}$. Fernando Marías cuando se refiere a la «librería» dice que podría emular a la de Sixto IV en el Vaticano ${ }^{3}$. Olga Marín, al tratar de la Sala Capitular ${ }^{4}$, recoge en nota algunas alusiones bibliográficas describiendo la catedral de Toledo, como la de Blas Ortiz (1549), que sitúa a la antigua «Librería» subiendo por una escalera situada en el aula derecha de la entrada principal al claustro ${ }^{5}$. Blas Ortiz no menciona ni se interesa por las pinturas de Borgoña, sino por el número copioso de libros que hay en ella y que estaban custodiados por un «guarda». Más exacto es el texto de Parro respecto a la ubicación de la Librería o biblioteca, a la que se llega desde la antesala del Cabildo de verano, a través de «una puerta mediana con su escalera bastante cómoda que conduce a la librería o biblioteca del Cabildo, que es una de las curiosidades más importantes que encierra la catedral y de las más dignas por consiguiente de la atención de los literatos y de los artistas por los antiquísimos y numerosos códices, y por las iluminaciones que muchos de ellos contienen». Un escritor de bastante consideración del siglo XVIII — sigue comentando Parro-, hablando de los obispos de Toledo, en la primitiva época de la Iglesia española, dice «que el Prelado Olimpio dio a la catedral una copiosa librería, y colocando a este obispo inmediatamente después de Asturio, resulta que siendo exacta la noticia, data la existencia de una librería en esta iglesia de principios del siglo XV». Pero sea lo que quiera de semejante dato, no puede dudarse que allá en el tiempo de los godos, debió de haber una colección de libros más o menos numerosa... pues aparte de los de Coro, cantorales, misales, breviarios, martirologios, etc., natural era que se guardasen aquí las actas de los Concilios generales, nacionales y provinciales, que se celebraban muy a menudo, y los libros de la Sagradas Escrituras, igualmente los escritos que por entonces publicaron tanto los prelados de Toledo, San Eugenio III, San Eladio, San Ildefonso y San Julián, como los de Sevilla, San Leandro y San Isidoro, y los de varias iglesias ilustradas en aquella época por varones insignes en santidad y ciencia; formando estas obras españolas, con las demás que tenían escritas y seguían escribiendo los Santos Padres y Doctores, una colección indispensable para la instrucción del clero, a lo menos en las materias eclesiásticas, que son las más importantes a su ministerio». Según Parro muchos de estos libros se pusieron a salvo enviándolos fuera de Toledo cuando la ciudad fue tomada por los musulmanes, sacándose de algunos copias y recuperandose otros cuando la catedral fue restaurada después de la Reconquista y de esta forma, se fue renovando la antigua «librería» enriqueciéndola con lo que se iba escribiendo por entonces. Parro opina que la colección no debió ser muy numerosa hasta fines del siglo XIV en que consta que el arzobispo Tenorio, uno de los hombres más sabios de su tiempo, donó a la catedral su copiosísima y selecta librería, edificando en el claustro, que entonces hacía construir, una pieza donde se conservase debidamente, «que es regular fuese en el mismo sitio que ahora ocupa». Al parecer la librería existía antes de que se comenzase el claustro, pues en 1380 el Papa Clemente VII prohibió que no se pudiesen extraer libros de la «librería de esta Santa Iglesia» ${ }^{6}$.

\footnotetext{
${ }_{2}$ Angulo, Juan de Borgoña. Madrid, 1954. Camón, Summa Artis, vol. XXIV. Madrid, 1970.

${ }^{3}$ F. Marías:,El largo siglo xvi: los usos artísticos del Renacimiento español. Madrid, 1989.

${ }^{4}$ O. Marín, «Las pinturas de la Sala Capitular de la Catedral de Toledo: Aportación al estudio de la concepción del Espacio», Archivo Español de Arte, 2000, p. 315-339.

5 B. Ortiz, La catedral de Toledo 1549. Toledo. Ed. A. Pareja, 1999. Cap. LIX.

${ }^{6}$ S. R. Parro, Toledo en la mano. Toledo, 1857 (T. I. p. 681-683, de la ed. 1978)
} 


\section{Genésis de la Librería o biblioteca en tiempos de Cisneros}

Parro nos dice que fue ensánchandose y mejorando la «librería» en tiempos del cardenal Mendoza y de Cisneros. Al ser este último el que encargó la decoración pictórica de la «Librería», nos ha parecido bastante interesante la revisión de la bibliografía sobre el cardenal por si hallábamos algún indicio sobre la misma. Curiosamente, el más inmediato biógrafo, su secretario Vallejo, no nos da ningún indicio sobre el tema, ocupándose solo de la ascendencia y vida política del cardenal ${ }^{7}$. Alvar Gómez de Castro, publica su biografía del cardenal en el año 1569 y, en ella, encontramos referencias a las diversas obras artísticas llevadas a cabo por Cisneros como fueron las obras de remodelación de la Capilla Mayor, con alusiones interesantes al «poco espacio del camarín». Pero, lo que más nos interesa es el párrafo en el que presenta al cardenal interesado en la restauración de la liturgia mozárabe hacia el año 1502: «visitó la biblioteca de la catedral y la encontró instalada en un recinto incómodo y mezquino, pues carecía de luz y aire y equipada con cicatería de libros, comenzó a estudiar el modo de equiparla con magnificencia y abundancia mayores y trasladarla a un lugar más adecuado. Sus propósitos se vieron interrumpidos por los numerosos quehaceres importantes en esos años» ${ }^{8}$.

Las noticias aportadas por Alvar Gómez de Castro, cuarenta y dos años después de la muerte de Cisneros, son fundamentales para comprender el empeño literario y artístico del Cardenal en la hechura de una nueva biblioteca, puntualizando sobre las noticias de Parro de que amplió la que había en el mismo lugar. La Librería antigua, que describe Gómez de Castro, era de reducido tamaño, sin luz y sin aire, atreviéndonos a sugerir su localización en un habitáculo de una entreplanta, interior, entre el actual Archivo Capitular y la Librería, según un plano del siglo xvil, que guarda la catedral (fig. 19). Desde el actual Archivo Capitular -a nivel del claustro alto- se accede por unos escalones a este «habitáculo» y fue a partir de él cuando se abriría una puerta a un espacio más amplio y con luz (la actual Librería) en un nivel inferior, al que se accedería por una escalera. Esto confirmaría lo escrito por Gómez de Castro, de que el Cardenal buscaba el traslado a otro lugar más amplio y luminoso.

Francisco de Pisa, en 1605, no hace ninguna mención a la librería ${ }^{9}$, hay que llegar a la obra de fray Pedro de Quintanilla y Mendoza, escrita en 1653, para hallar un testimonio preciso sobre el lugar y las pinturas de la Librería: «... En una sala de más importancia que caía encima de la capilla de San Pedro había una reja grande a donde asistía su majestad en las horas Divinas... Labro [el cardenal] la escalera principal que sube del claustro bajo al claustro alto y está junto a la capilla del arzobispo Tenorio. Lo dice el Doctor Blas Ortiz que lo vio. Conforme corría la fábrica del claustro principal fabrico a su costa la sala que llaman del Capítula y la Librería que hoy tiene la iglesia. Había entre la Capilla de San Pedro y la Capilla del arzobispo Tenorio un espacio muy imperfecto que salía a la chapinería y allí trazo tres cosas: Puerta principal para entrar y salir la reina sin apearse de la iglesia. Y en este mismo tránsito en lo que quedaba hasta la capilla Tenorio hizo un oratorio o capilla donde hay tradición confesaba la reina. Luego le dieron a esta capilla el nombre de Sala del Capítulo y de eso ha servido hasta que en nuestros tiempos don Álvaro Monsalve, Obrero Mayor la renovó y blanqueó y adornó de unas puertas muy de su ingenio y devoción que tuvo al siervo de Dios Francisco Ximenez de Cisneros, pues por ser esta capilla donde se celebraba porque no se perdiese esta tradición y memoria bolbio a poner sus armas de piedra y las antiguas de dicha puerta.

${ }^{7}$ J. Vallejo, Memorial de la vida de fray Francisco Jiménez de Cisneros. Publicada con prólogo y notas de A. de la Torre y del Cerro. Madrid, 1913.

8 A. Gómez de Castro, De las hazañas de Francisco Jiménez de Cisneros. Alcalá, 1569. Ed. fácsimil Madrid, Fundación Universitarios Española, 1984.

${ }^{9}$ F. de Pisa, Descripción de la Imperial ciudad de Toledo, Toledo 1605.

AEA, LXXVI, 2003, 301, pp. 5 a 21 
También en esta fábrica se hizo la Librería principal que hoy goza esta Santa iglesia que está en un entresuelo, entre la dicha Sala Capitular y los cuartos altos de lo demás de la fábrica y caen las bentanas a la calle de la Chapinería y parece por lo mismo obra que se hizo a un mismo tiempo y antes implicaba labrarse lo uno sin lo otro. Es esta sala muy espaciosa toda ella pintada por el mismo señor cardenal como parece está llena de sus escudos y de los dotores clásicos de su misma orden. Adornola de los libros que corrían en su tiempo y de costosos estantes y asientos, toda ella tan bien dispuesta que con ser antigua compite en su hermosura con muchas modernas. En esta librería en tiempos de Cisneros se leía la Sagrada Escritura a prima noche. $\mathrm{Y}$ es constante que en todo su tiempo cuando el costeaba la obra aparezca su escudo» ${ }^{10}$. Quintanilla también alude a que la Sala Capitular «como la librería» fue costeada por el cardenal de su erario personal.

El espacio de la librería en el entresuelo, sobre la Sala Capitular de verano actualmente convertida en almacén, existe hoy y se utiliza como librería, comunicándose con la antigua Sala Capitular de verano por una escalera y con las habitaciones que dan al claustro - hoy Archivo Capitular - por otra (figs. 16-18).

El picado de las pinturas y el blanqueado final que acabó con ellas, debió llevarse a cabo en el siglo XVIII en tiempos del cardenal Lorenzana ( $† 1804)$ cuando este organiza su biblioteca poniendo al cargo de ella como bibliotecario a Pedro Hernández. Lorenzana también picó, y blanqueó las pinturas al fresco de la Capilla del palacio Arzobispal de Alcalá de Henares, pintadas por Correa de Vivar en tiempos del cardenal Fonseca y sobre las que volveremos a propósito del programa iconográfico de la Librería ${ }^{11}$.

La destrucción de las pinturas debió ser posterior al año 1777, en que fray Nicolás A. de Alcolea describe la Librería de Cisneros adornada con pinturas, estantes y mesas, destacando que el cardenal «tuvo pensamiento que compitiese con la del Vaticano», ya que guardaba los libros más selectos que había entonces, y en gran número ${ }^{12}$.

Recogiendo los testimonios de Gómez de Castro y de Alcolea, Hefele, uno de los más importantes biógrafos de Cisneros, nos vuelve a hablar de la librería y del por qué del interés de Cisneros en su construcción: la visita que hace el cardenal a la Biblioteca de la Catedral en 1502, y el descubrir los manuscritos mozárabes en mal estado de conservación, le hacen resolver de inmediato la construcción de un local mejor situado, más espacioso y con mejores luces, dotándolo de las rentas necesarias y digno en todos los conceptos de rivalizar con la $\mathrm{Bi}$ blioteca Vaticana. Alvar Gómez de Castro llamó la atención sobre los muchos quehaceres que tuvo el Cardenal por aquellos años y que fueron la causa de que se retrasara la obra de la $\mathrm{li}$ brería desde 1502 hasta 1517, en que por fin se lleva a cabo. Hefele puntualiza que el Cabildo se opuso a su realización por los muchos gastos que el cardenal tenía en Alcalá con la creación de la Universidad y la impresión de la Biblia ${ }^{13}$. Esta noticia contradice la dada por Quintanilla de que fue costeada particularmente por Cisneros.

\footnotetext{
${ }^{10}$ Fray P. Quintanilla y Mendoza, Archetipo de Virtudes. Espejos de Prelados el venerable y siervo de Dios Fray Francisco Ximenez de Cisneros. Palermo, 1653, f. 111-112. O. Marín Cruzado, loc. cit. nota 4, en la última nota al texto hace algunas alusiones a la «Librería», haciendo referencia al texto de Blas Ortiz, Descripción graphica y elegantissima de la S. Iglesia de Toledo, (1549), reed. Madrid, 1599, a propósito de la ubicación de la librería. También alude al trabajo de R. Gonzálvez Ruiz, «Blas Ortiz y su mundo» en la Catedral de Toledo en el que se recoge la noticia de que el cardenal Tavera quiso ser enterrado en la catedral fundando una capilla donde ahora está la librería que describe con siete bóvedas, y que ha sufrido continuos cambios. Pensamos que tal vez el proyecto de capilla funeraria con retablo debido a Juan Correa de Vivar que publiqué (I. Mateo Gómez, «Retablos de Juan Correa de Vivar para una capilla funeraria no localizada» en Homenaje al Profesor Martín González. Valladolid, 1995, pp. 525-531) pudo ser para este lugar.

1 I. Mateo Gómez, «El programa humanista de la fachada de la Universidad de Alcalá de Henares», en La Universidad de Alcalá, vol. II. Madrid, 1990, pp. 273-275.

${ }^{12}$ Fr. N. A. Alcolea, Seminario de nobles. Taller de venerables y doctos, el colegio mayor de San Pedro y San Pablo..., Madrid, 1777.

${ }_{13}$ Ch. J. Hefele, El cardenal Cisneros y la Iglesia española, Barcelona, 1869.
}

AEA, LXXVI, 2003, 301, pp. 5 a 21 


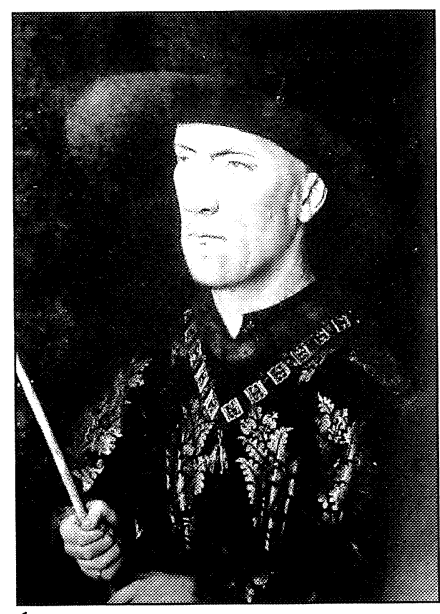

1
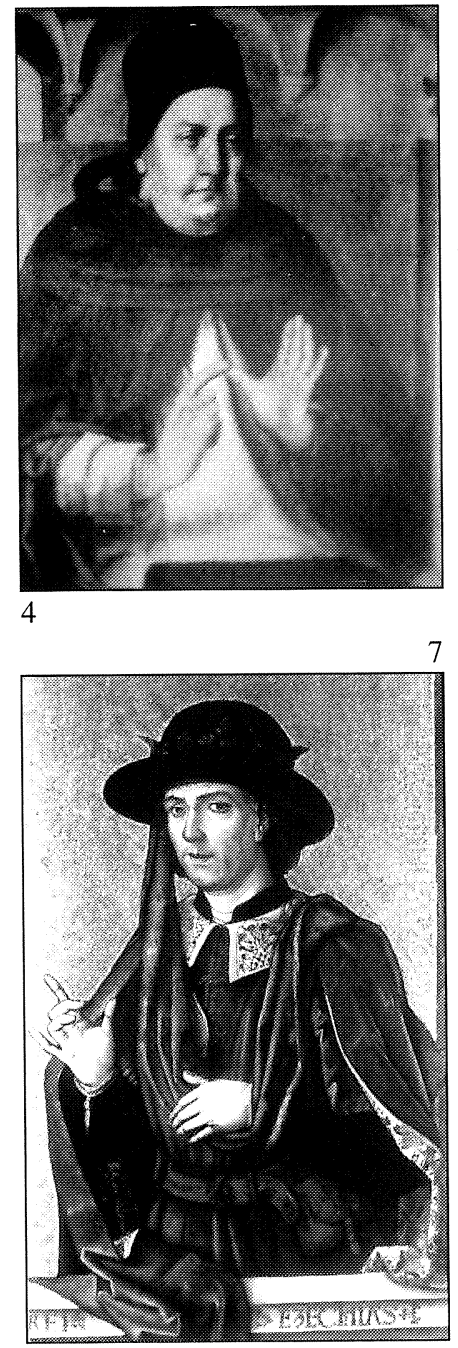

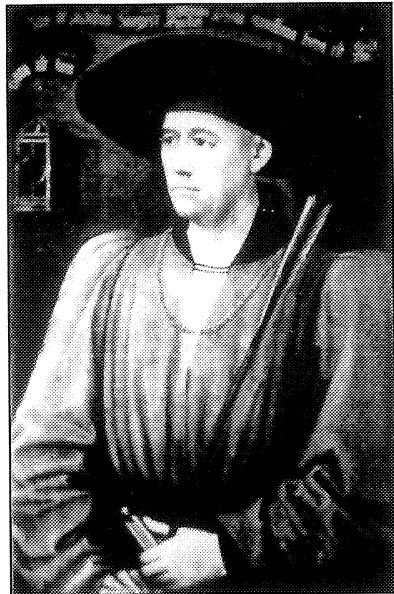

2

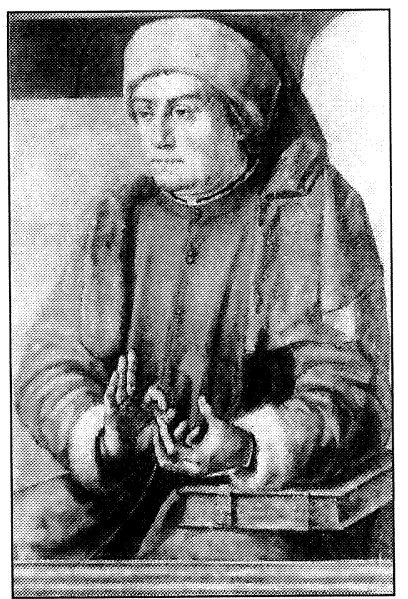

5

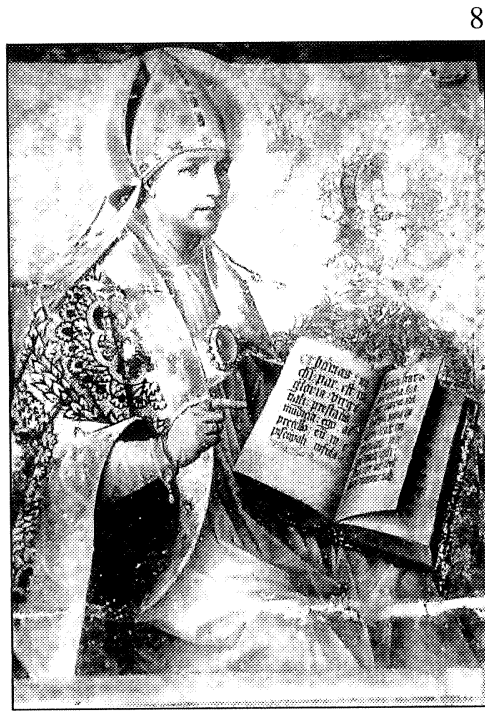

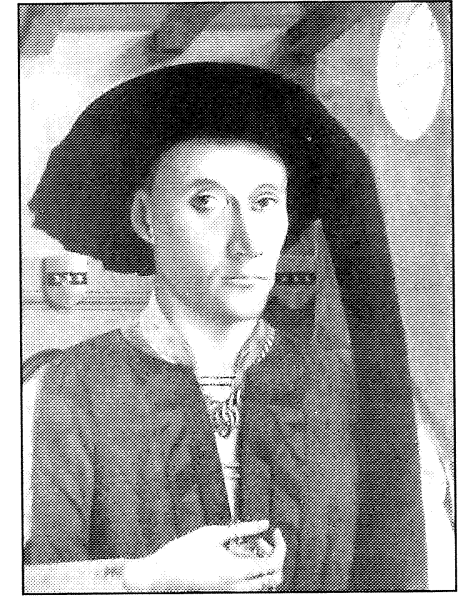

3

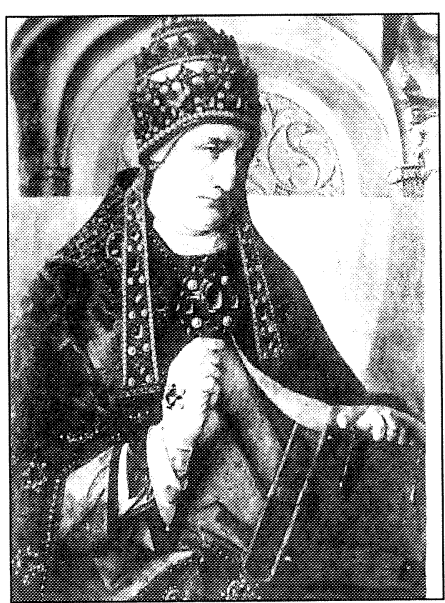

6

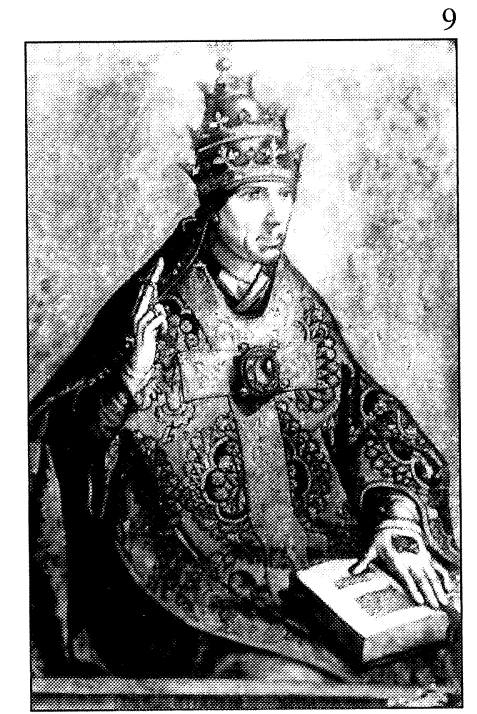

Figs. 1-3. Retratos por Van Eyck, Van der Weyden y Petrus Christus.

Figs. 4-6. P. Berruguete, Hombres famosos. Urbino, Palacio Ducal.

Figs. 7-9. P- Berruguete, Bancos de retablos. Paredes de Nava, Catedral de Ávila, Madrid. Col. privada.

$A E A$, LXXVI, 2003, 301, pp. 5 a 21 
En efecto, el enfrentamiento de Cisneros con el Cabildo toledano arranca desde el año 1495, cuando quiso que los canónigos viviesen en el claustro alto haciendo vida de comunidad, teniendo que destinar, después, estos aposentos para las visitas reales, al negarse los canónigos a vivir como frailes. San Román nos habla de la sorpresa del embajador Navagero ante la riqueza y fastuosidad en que vivían los canónigos de Toledo, tipo de vida que se extendía a todo el mundo religioso de fines de la Edad Media y comienzos del Renacimiento, y que propició el intento reformador de Cisneros en España ${ }^{14}$.

Además de estos problemas hubo otros, tanto de orden económico, como político. Recordemos que Cisneros encarga a Rodrigo Alemán la sillería de coro y casi al mismo tiempo, en 1498, comienza la transformación de la Capilla mayor y la hechura del nuevo retablo de la catedral, y las obras del palacio arzobispal de Alcalá. Pero, además, en 1500 encarga el Misal y en 1502 un Breviario, año justamente en que también empiezan sus inquietudes por la hechura de la Librería nueva. En 1505 comienzan los problemas políticos con Orán, en 1506 es nombrado, en ausencia de Fernando el Católico, Gobernador del reino y, al año siguiente de 1507, en que recibe el capelo cardenalicio, se declara una epidemia de peste en Castilla. Es después de la conquista de Orán cuando se decora la capilla mozárabe con escenas reveladoras de Cisneros, como político y guerrero tomando las plazas africanas. Juan de Borgoña se encarga de ello y dura su trabajo de 1508 al 1512, contratando entre medias con el cardenal, la pintura de la Sala Capitular, entre 1509 y 1511. Por todos estos motivos, la decoración de la librería tuvo pues que posponerse hasta el año 1517, justo el año en que muere Cisneros.

La bibliografía del siglo xx sobre el Cardenal no se ocupa de la librería, y aunque cita la intervención de Cisneros en la Sala Capitular, Capilla mozárabe, altar de la catedral, conventos de San Juan de la Penitencia en Toledo y en Alcalá, y la universidad y colegios de este último lugar, centran más su atención en la faceta del Cardenal como mecenas literario, destacando su labor en la Biblia Políglota, labor a la que algunos suman la creación del Archivo de Simancas, basándose en la carta de Cisneros a López de Ayala: «acordamos de hacer unos archivos donde todas las dichas escrituras se pongan e guarden...». Gómez de Castro, en el Libro VI, dice que no llegó a llevarse a cabo y que los documentos se llevaron primero al Castillo de la Mota, y en 1534 a Simancas por orden de Carlos V ${ }^{15}$

La confección de la Biblia Políglota, que se inicia en 1502, atrajo a eminentes humanistas como Nebrija, El Pinciano, López de Zúñiga, Juan de Vergara —amigo de Erasmo con el que compartía Cisneros la necesidad de que la Iglesia conviviera con el espíritu humanístico del mundo-, Alfonso de Zamora y Alfonso de Alcalá, entre otros. La idea surge de un hombre enamorado del saber y de las letras, interesado en restablecer los estudios bíblicos. Esta sensibilidad de Cisneros y la de la reforma del clero creemos que inspiró la idea de lo que debió de ser el programa pictórico de la Librería, el de instruir al clero a través del ejemplo de los varones insignes en santidad y ciencia, muchas de cuyas obras se guardaban en ella, y no sólo a la representación de los «doctores de su orden», como simplificó Quintanilla. Pero su labor no se limitó a la Biblia Políglota, sino que según Fernández de Retana, al ver arrumbados en aposentos de la catedral, aquellos «venerables y antiquísimos libros que habían servido a los hispanogodos, resolvió reinstaurar el culto mozárabe y buscó por toda la diócesis y fuera de ellas manuscritos y códices del rito» ${ }^{16}$.

\footnotetext{
${ }^{14}$ San Román, «Cisneros y el Cabildo Primado al finalizar el año 1503», Boletín de la Real Academia de Bellas Artes y Ciencias Históricas de Toledo. Año II, 1919, n. ${ }^{\circ} 3$, pp. 1-32. J. García Oro, Cisneros , el cardenal de España. Barcelona, 2002.

${ }^{15}$ L. Fernández de Retana, Cisneros y su siglo. Madrid, 1929. Gómez de Castro, loc. cit., nota 8. Guisasola y Menéndez, Cardenal y arzobispo de Toledo: IV Centenario de la muerte de Cisneros. Toledo, 1917. Cedillo, Conde de, Cisneros gobernador del reino. Madrid, 1921.

${ }^{16}$ L. Fernández de Retana, loc. cit. not 15. J. López de Toro, Perfiles humanos de Cisneros. Madrid, 1958.
}

AEA, LXXVI, 2003, 301, pp. 5 a 21 


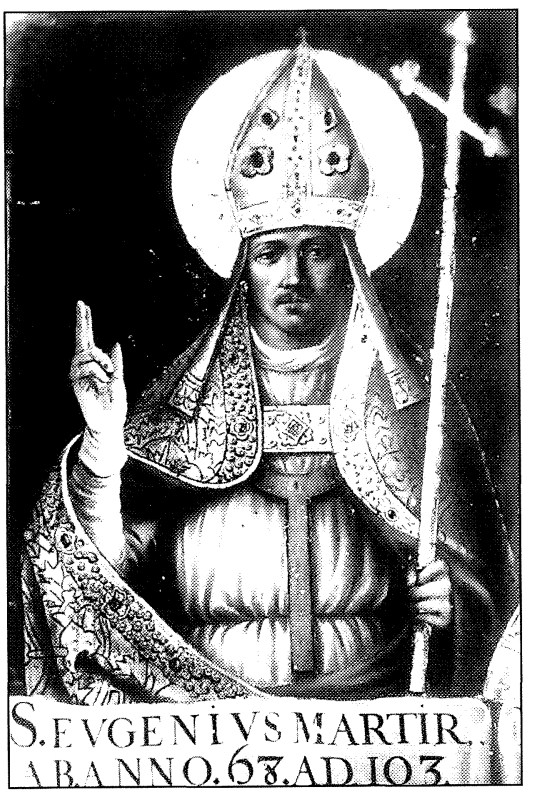

10

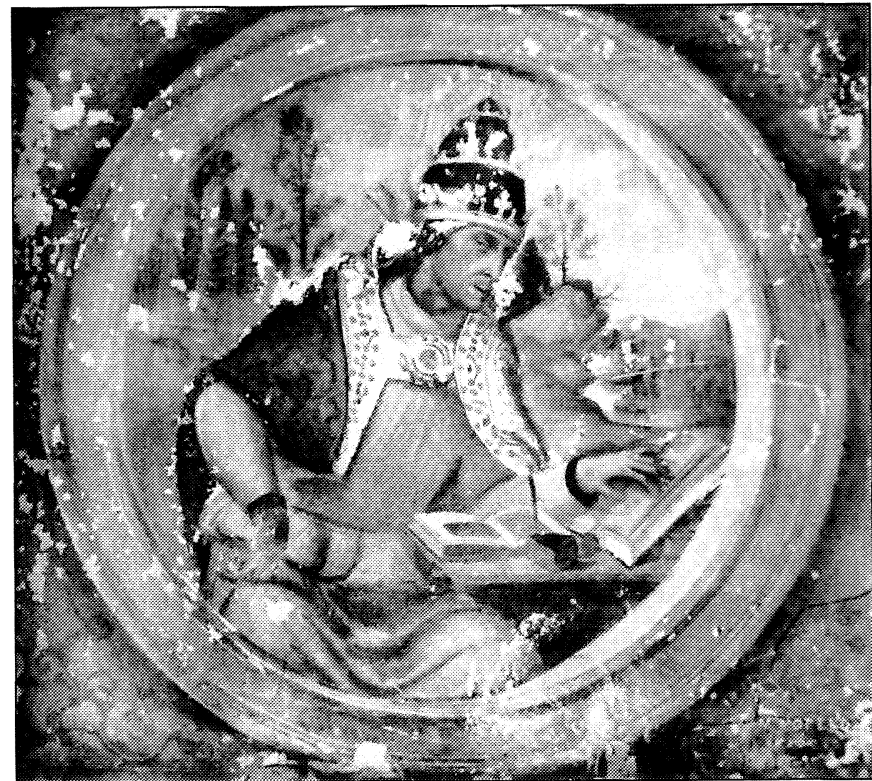

12

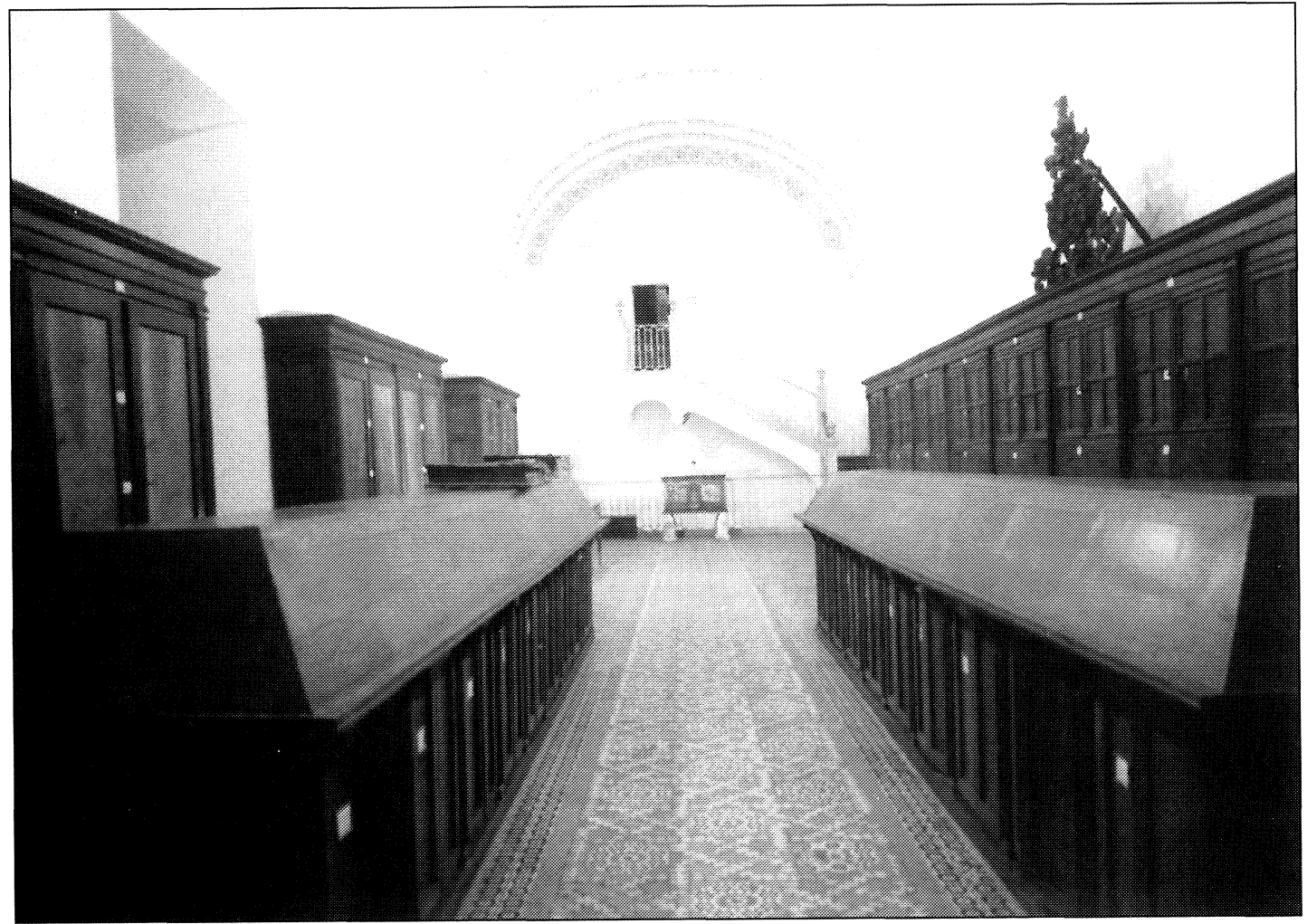

Figs. 10-11. J. de Borgoña, Sala Capitular; J. Correa de Vivar, San Gregorio, Capilla del Palacio Arzobispal de Alcalá de Henares (desaparecido).

Fig. 12. La Librería de la catedral de Toledo, en la actualidad, con la remodelación del s. XVIII, con la escalera de bajada desde el habitáculo que pudo ser la librería antigua y con el pavimento original de Cisneros.

AEA, LXXVI, 2003, 301, pp. 5 a 21 
Aunque todavía no está bien estudiada la biblioteca cisneriana, todos sus biógrafos destacan en ella su admiración por los Padres de la Iglesia y por otras obras como las Meditaciones de la Vida de Cristo, del Cartujano, la Vida de Santa Catalina y de la bienaventurada Juana de Orbieto y Sor Margarita de Castello, Cartas de Santa Catalina, Opúsculos de Santa Ángela Foligno y Santa Matilde, Grados de San Juan Climaco, Instituciones de San Vicente Ferrer y Santa Clara, Vida de Santo Tomás de Cantorbery, Obras de Raimundo Lulio — de quien era gran admirador- Obras del Tostado, amén de obras de Aristótles, Cicerón, la Erotemala de Crisoloras, Hero y Leandro, de agricultura. A su biblioteca sumó los libros de sus antecesores y muchos de ellos fueron traducidos en Toledo y Alcalá, entre los años 1502 y $1514{ }^{17}$. Otras obras eran «de varias materias provechosas, aun en el orden temporal» ${ }^{18}$.

A este aspecto bibliófilo de Cisneros, suma Fernández de Retana, el de su interés por tener una tertulia con personajes ilustres en ciencia y virtud, reuniendo a su alrededor a un grupo de sabios y doctores para ilustrar sus conversaciones sobre teología, filosofía y derecho. Entre ellos se hallaban los que hemos citado como colaboradores en la traducción de la Biblia, pero hay que sumar al teólogo Nicolás de Paz, admirador también de Lulio. Estas tertulias tenían lugar en el estudio del cardenal, por la noche ${ }^{19}$.

La más reciente biografía de Cisneros es la de García Oro, en la que cita la visita del cardenal, en 1502, a la antigua Librería, donde descubre los códices mozárabes, y cómo su corte de humanistas le asesoran sobre ellos, comentándole que eran los que usó San Ildefonso de Toledo, revelándolos Cisneros con dos pasos importantes: la edición de los textos mozárabes y la construcción de una capilla mozárabe en el mismo recinto de la catedral. También alude a la necesidad que halló Cisneros de recoger cuidadosamente las escrituras y libros para colocarlos ordenadamente en locales apropiados ${ }^{20}$.

De este repaso biográfico por la faceta «intelectual» del cardenal, podemos sacar en conclusión, el interés que para él debió tener, en fecha tan temprana como la de 1502, la hechura de una Librería que reuniera las condiciones necesarias para albergar los códices mozárabes y los espléndidos manuscritos y libros de sus predecesores, que él había salvado de la ruina, enriqueciéndola con nuevas adquisiciones.

En el año 1502, cuando se comienza a pensar en la nueva Librería, Juan de Borgoña colaboraba en las pinturas del claustro, en el que había pintado P. Berruguete, según noticia de Pérez Sedano, de 1495, «hay razón en el Cabildo de que éste mandó que pintase en la claustra y lo hiciese Berruguete» ${ }^{21}$. Esta noticia hace pensar que fuera el pintor palentino el que dirigiera el proyecto pictórico del claustro y entre los que colaborarían con él se hallaba Juan de Borgoña pintando la «historia de la Visitación». Este documento y la presencia de Berruguete en otros empeños importantes de la catedral, como la pintura del Sagrario, la de la capilla de San Pedro y la de la tabla de la Esperanza, etc., presentan al pintor como un artista considerado por el Cabildo toledano durante las Sedes de los cardenales Mendoza y Cisneros, es decir, desde 1483 hasta 1500 , en que no aparece ya en los documentos catedralicios.

Juan de Borgoña, una vez desaparecido Berruguete de la catedral, todavía entre los años 1500 y 1504 , se hallaba trabajando en labores menores como la policromía del retablo mayor y pintando en el banco del mismo, con los pintores Rincón, Medina y Flores ${ }^{22}$. Su primera obra importante es el contrato que lleva a cabo entre 1504 y 1505, obligándose a pintar el retablo

\footnotetext{
${ }^{17} \mathrm{La}$ inclinación del cardenal por la literatura de las santas, a la que suma la de Santa Lutgarda, aparece recogida por P. Sainz Rodríguez, La siembra mística del Cardenal Cisneros y las reformas de la Iglesia. Madrid, 1979.

${ }_{18}$ Guisasola y Menéndez, loc. cit., nota 15.

${ }^{19}$ Fernández de Retana, loc. cit., nota 15.

${ }^{20}$ García Oro, loc. cit., nota 14.

${ }_{21}$ Pérez Sedano y Zarco del Valle, Datos documentales para el estudio del arte español. Madrid, loc. cit. nota 1.

22 Loc. cit. nota 21.
}

$A E A$, LXXVI, 2003, 301, pp. 5 a 21 

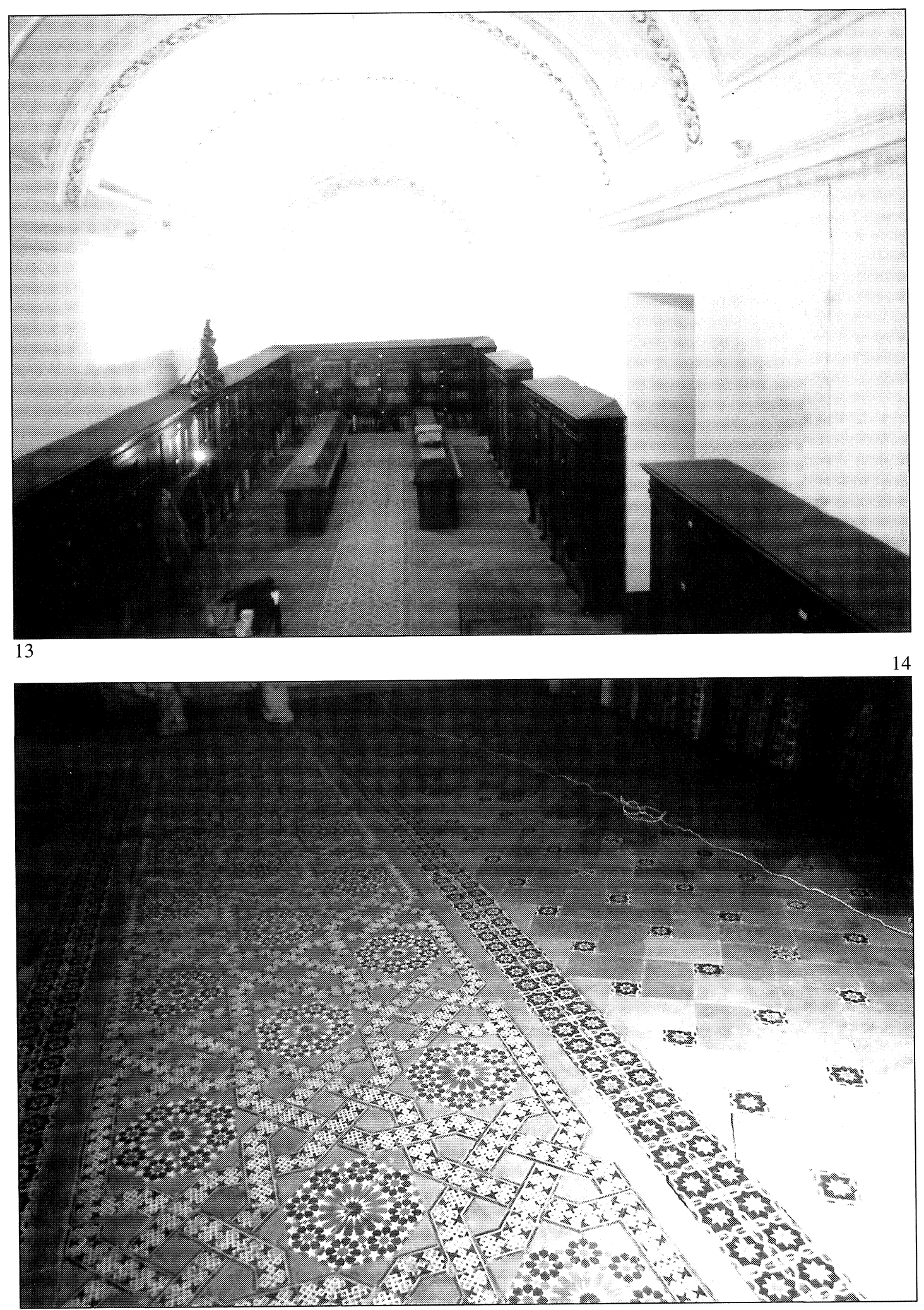

Fig. 13. La Librería de la catedral de Toledo, en la actualidad; las ventanas a la derecha. Fig. 14. Pavimento de la Librería, de la época de Cisneros. 
para la Capilla de don Luis de Daza, capellán mayor del rey y canónigo de la catedral, con el tema de los Tres Reyes Magos y la Pasión ${ }^{23}$.

En este retablo se nos muestra Borgoña como un pintor de técnica muy fina pero sin ninguna preocupación espacial, que tampoco consigue en las pinturas de la Capilla Mozárabe, en 1508. La primera obra en la que el pintor se nos muestra con estas preocupaciones es, precisamente, en el retablo mayor de la catedral de Ávila, sin duda diseñado por Pedro Berruguete y a quién sustituye por fallecimiento de éste.

$\mathrm{Al}$ año siguiente, de 1509, se le encarga la decoración al fresco de la Sala Capitular de Toledo, en la que pinta hasta el 1511, alternándola con el retablo de Ávila. En Ávila debió conocer también, el conjunto pintado por Pedro Berruguete para el convento de Santo Tomás, y todos los estudiosos que se han ocupado de la obra más sobresaliente de Borgoña, la Sala Capitular de la catedral toledana, han destacado el sustrato de Berruguete que se detecta en ella, no sólo en el gusto por las cubiertas moriscas, sino por el sentido espacial en que se desarrollan las escenas, a través de estructuras arquitectónicas fingidas de vanos abiertos, separados por pilares ${ }^{24}$. Pero hay algo más, inspirado por el arte de Berruguete, en la Sala Capitular, y son las setenta y dos figuras de arzobispos, de tres cuartos, evocadores de los «hombres sabios» de Urbino, de los diversos bancos de los retablos castellanos pintados por Berruguete y de la forma de retratar, en general, los primitivos flamencos, concretamente Petrus Christus, Van der Weyden y Van Eyck, del que tanto Justo de Gante como Berruguete fueron admiradores (figs. 1-10). La Sala Capitular ofrece dos órdenes de historias pintadas, la superior con los temas sagrados, y la inferior con los obispos. En el Sagrario, pintado por Berruguete, según la documentación de la catedral de Toledo, del año 1488, publicada por Pérez Sedano, el pintor se compromete a acabar todas las historias que faltaban «debajo de la primera orden de historias pintadas de su mano y del maestro Antonio». De nuevo una traza similar, a dos bandas, como en Urbino.

Este gigantesco paso pictórico en el arte de Juan de Borgoña en la Sala Capitular, nos ha hecho meditar sobre unas palabras de Ponz, en su Viaje por España, recogidas y comentadas por Pérez Sedano, en las que dice «que tiene bien entendido que habían sido realizadas por Pedro Berruguete...». Pienso que es obra de Juan de Borgoña, pero tal vez debiéramos considerar si es que se dejó influir por lo conocido de Berruguete en Urbino y en España, o, además, por alguna traza que el palentino hizo para la Sala Capitular para la catedral toledana.

\section{Función e idea de la Librería}

Como hemos visto, su hechura se debe al interés bibliográfico de Cisneros por la conservación de los extraordinarios libros que había encontrado en estado de abandono en la antigua biblioteca, y por la suma de las nuevas adquisiciones y traducciones de Alcalá y Toledo, considerando la necesidad de un lugar mejor acondicionado, y de mayor amplitud. En el talante humanista de Cisneros y tal vez de sus contertulios y colaboradores en la Biblia, a los que ya nos hemos referido, pudo ir gestándose el programa iconográfico, que exaltaría a los hombres ilustres del mundo cristiano y tal vez a aquellos paganos de fuerte espíritu moral, de los que el cardenal conservaba obras. Durante los periodos inmediatamente anteriores a la época de Cisneros, había surgido una literatura con estos mismos sentimientos de exaltación moral, de los que puede ser un buen ejemplo, en Italia, Petrarca con sus Hombres Ilustres, fuente sin duda, para el programa de Federico Montefeltre en Urbino, y para la decoración de los Hombres Ilustres de Pa-

${ }^{23}$ C. Torroja, Catálogo del archivo de obra y fábrica. Toledo, 1977. Libros de Obra, años 1504-1505, n. ${ }^{\circ} 1097$.

${ }^{24}$ Angulo, Ars Hispaniae, loc. cit. nota 2; Camón, Summa Artis, loc. cit. nota 2. F. Marías, El largo..., loc. cit., nota 3. O. Marín, loc. cit., nota 4.

$A E A$, LXXVI, 2003, 301, pp. 5 a 21 


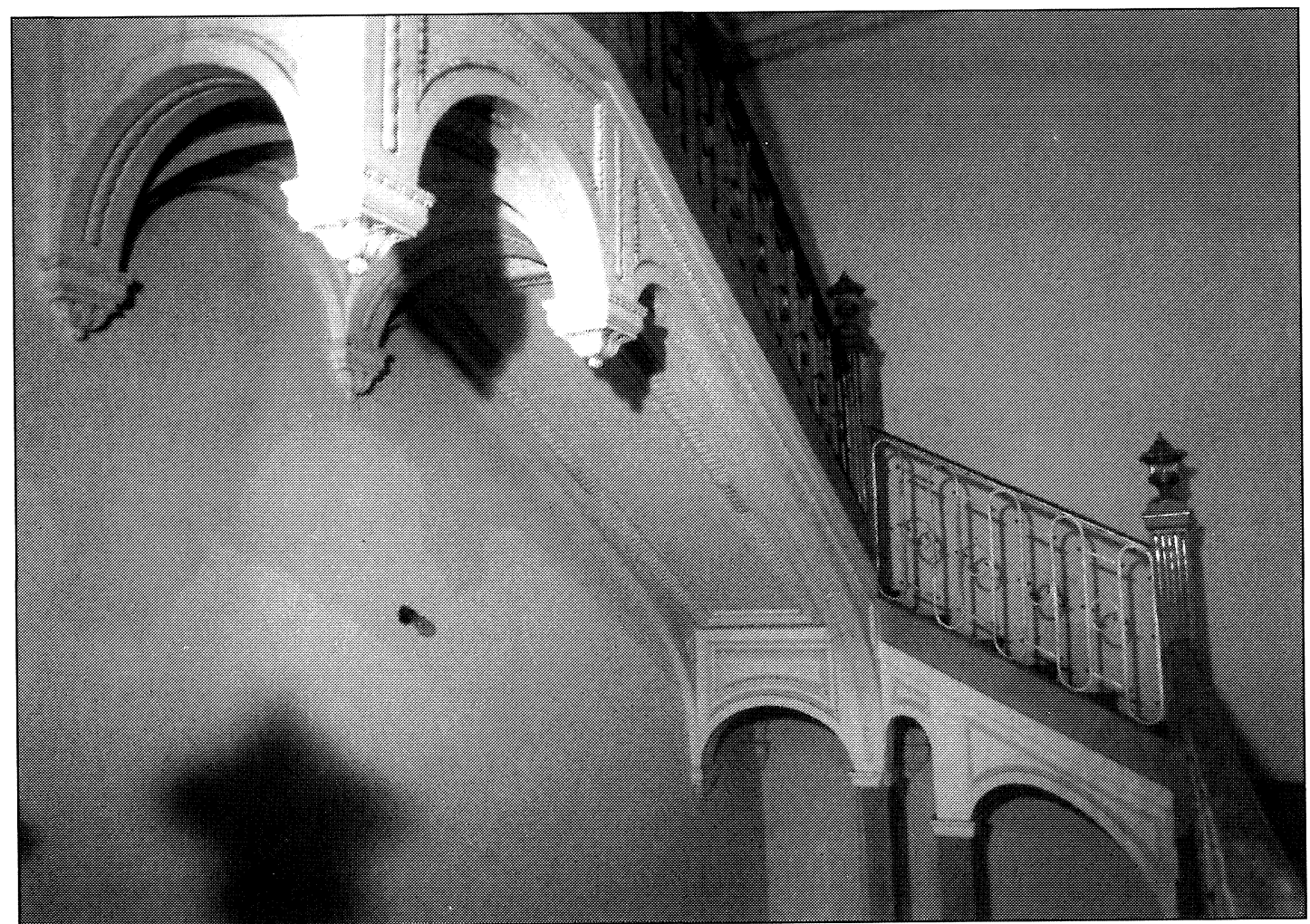

15

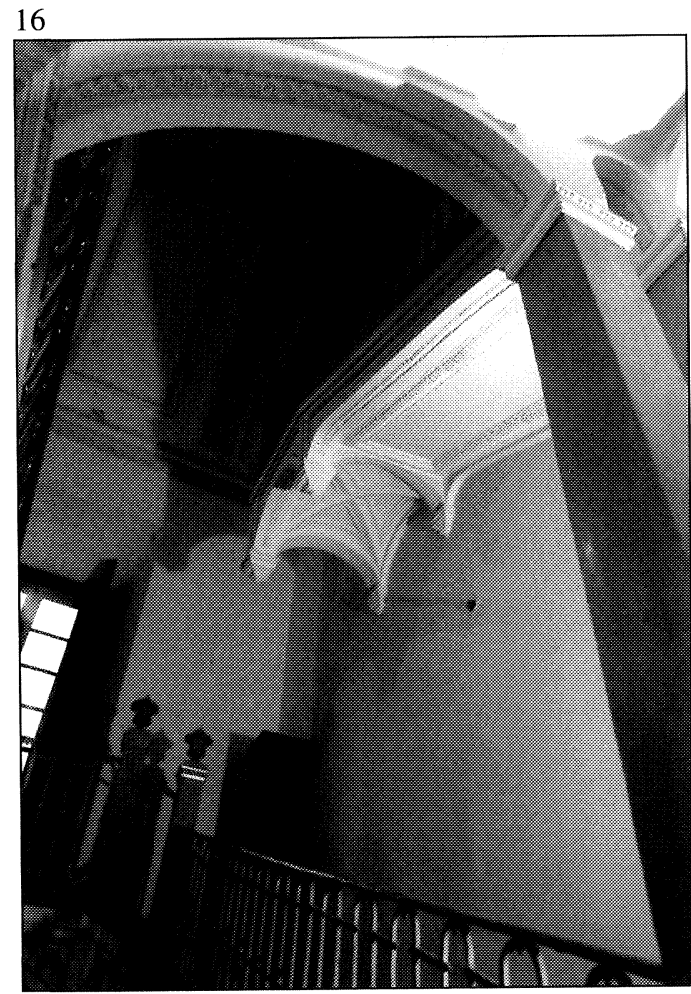

17

Fig. 15. Escalera de bajada a la Librería, con remodelación del siglo XVIII.

Figs. 16-17. Escalera de bajada desde la Librería a la antigua Sala Capitular de Verano.

AEA, LXXVI, 2003, 301, pp. 5 a 21 
dua. Estas fuentes y las aportadas en España por Fernán Pérez de Guzmán en dos libros importantísimos, Floresta de los Philosofos y Generaciones y semblanzas, destacando a los grandes sabios y letrados, pudieron ser tenidos en cuenta para el programa de la Librería de Cisneros.

Sin mermarle ningún mérito a Borgoña, pensamos que Cisneros pudo haberle encargado la traza a Pedro Berruguete, por contar con la experiencia de Urbino. Ello estaría de acuerdo con la noticia que verbalmente me ha dado el canónigo archivero de la catedral de Toledo, don Ramón Gonzálvez, de que hace años se tropezó con unos papeles sueltos que relacionaban a Berruguete con la Librería. Ello me hace pensar si la noticia dada por Pérez Sedano y Zarco ${ }^{25}$, del 16 de febrero de 1516, en la que se dice que empieza la obra Juan de Borgoña pero las condiciones no son suyas, sino de Pedro de Gumiel, no estará mal leída, pues al estar Pedro Berruguete muerto desde hacía muchos años, se pudo interpretar que debía tratarse de Gumiel, todavía arquitecto en nómina entre los servidores de Cisneros ${ }^{26}$.

Berruguete llega a la catedral de Toledo al parecer en tiempos del cardenal Mendoza, un año después de la muerte de Carrillo. El prestigio del pintor era lo suficientemente importante para que Cisneros continuara con sus servicios en la catedral, pero, además, tal vez había un factor de orden sentimental, ambos procedían de Tierra de Campos y un pariente de su padre, Rodríguez de Cisneros, prospera en Paredes de Nava - la tierra natal de Berruguete- como oficial y letrado de la monarquía ${ }^{27}$.

La descripción de las pinturas de la Librería, hecha por Quintanilla, «en esta sala muy espaciosa toda ella pintada por el mismo señor cardenal como parece esta llena de sus escudos $y$ de los dotores clásicos de su misma orden...» ${ }^{28}$, la pone directamente en relación con el programa de Urbino y con los importantes bancos de profetas y Padres de la Iglesia, pintados por Berruguete, unas veces de medio cuerpo y otras de cuerpo entero.

Me inclino a pensar que los Santos Padres clásicos a los que se refiere Quintanilla, son los Padres de las Iglesias griega, latina y española, es decir: San Atanasio, San Basilio, San Gregorio Nacianeceno, San Juan Crisóstomo, San Gregorio, San Jerónimo, San Ambrosio, San Agustín, San Ildefonso, San Eugenio, San Isidoro y San Leandro, los ocho últimos esculpidos por Fancelli, precisamente, en el sepulcro del cardenal Cisneros, acompañados por otros hombres ilustres, como ya se ha dicho ${ }^{29}$.

Estos varones eclesiásticos ilustraron y defendieron por escrito el dogma católico y, en este concepto pueden incluirse muchos escritores en quienes no concurren los caracteres estrictos de «Padre», pero con los que puede apreciarse el mejor desenvolvimiento cultural de la Iglesia.

A estos Padres de la Iglesia de los que creemos indispensable su presencia en la Librería de Cisneros, tal vez habría que sumarles, como hemos dicho, los considerados de la Iglesia Griega: San Atanasio, San Basilio, San Gregorio Nacianeceno y San Juan Crisóstomo, quienes se vieron honrados por su santidad y erudición con el título de doctor. La conversión del estado pagano al cristianismo acaecida a comienzos del siglo Iv, cambió profundamente las condiciones de la sociedad de aquel entonces. Libre ya la Iglesia de enemigos exteriores desarrolla en todos los ramos de la ciencia teológica una actividad literaria fecunda y amplia, semejante a la que muchos siglos después, por otras necesidades, quiso llevar a cabo Cisneros. La Patrología después de San Agustín alcanza su más importante desarrollo en Occidente, contribuyendo a ello la poderosa corriente de ideas establecidas entre el mundo griego y el latino, cuyos guías providenciales fueron San Atanasio, San Jerónimo y San Hilario. Hubo grandes herejías

${ }^{25}$ Pérez Sedano y Zarco, loc. cit. nota 1, n. $^{\circ} 44$.

${ }^{26}$ A. de la Torre, «Servidores de Cisneros», Hispania, XXIII, 1946.

27 García Oro, loc. cit., nota 14.

28 Loc. cit., nota 10.

${ }^{29}$ Marchamalo Sánchez y Marchamalo Main, El sepulcro del Cardenal Cisneros. Alcalá de Henares, Madrid, 1985.

AEA, LXXVI, 2003, 301, pp. 5 a 21 

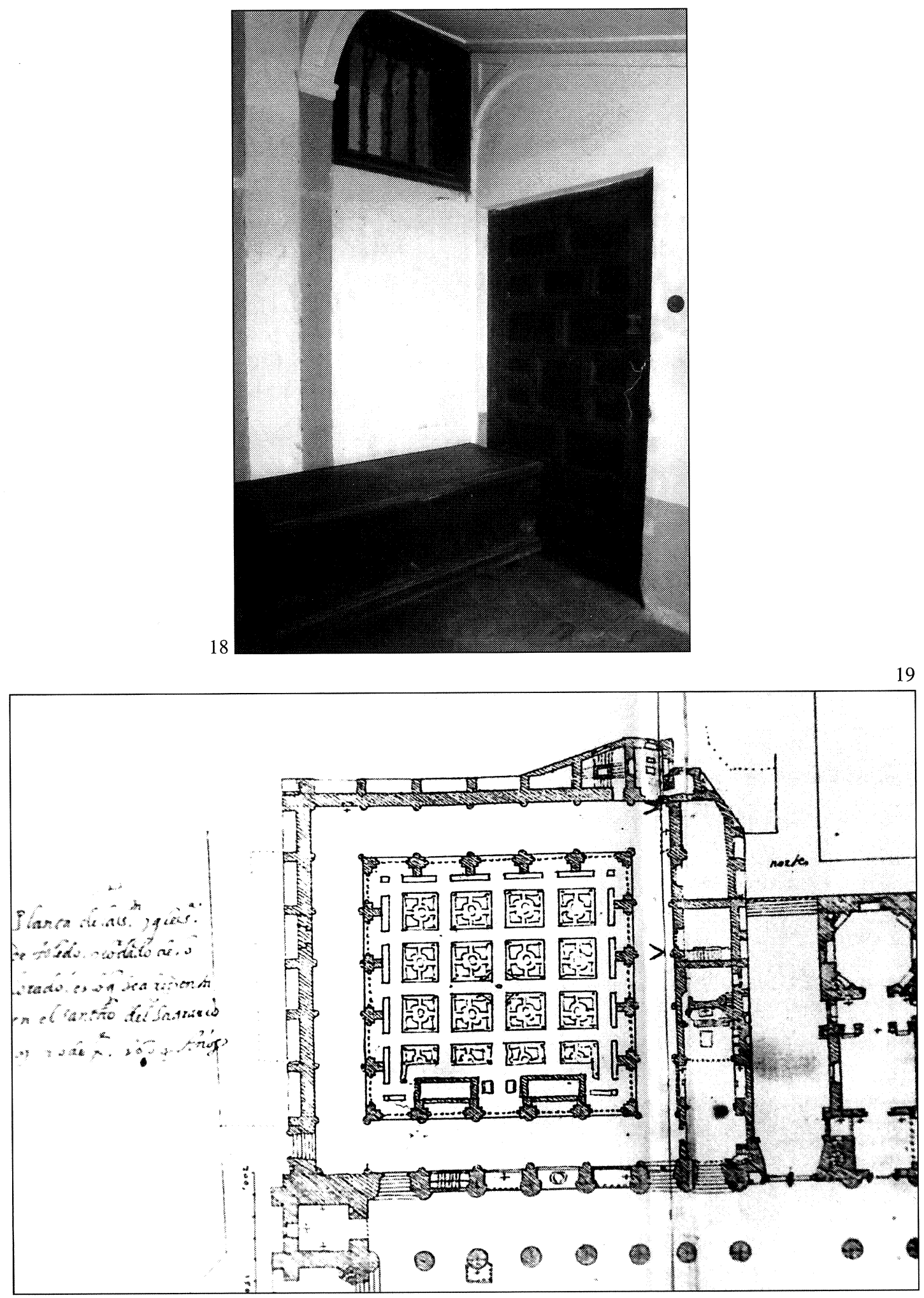

Fig. 18. Entrada a la antigua Sala Capitular de Verano.

Fig. 19. Detalle del plano de 1604 de la catedral de Toledo donde se puede observar entre el lado norte y el claustro [ $>>$ ] el espacio de la Librería.

$A E A$, LXXVI, 2003, 301, pp. 5 a 21 
debido precisamente, en gran parte, al despertar intelectual de la Iglesia y con los trabajos de los Padres quedaron dilucidados los dogmas de la Trinidad, la Encarnación, Redención y Gracia. Ellos en sus sermones y escritos desenmascararon los sofismas más sutiles de la herejía.

En los albores de la ciencia teológica (s. III y comienzos del iv) se había sentido la necesidad de desarrollar científicamente la doctrina eclesiástica y de consolidarla histórica y exegéticamente, fundamentándola sobre robustos cimientos religiosos, abriendo nuevos caminos y descubriendo amplios horizontes contra los que la perseguían, preparando el florecimiento teológico, que vendría después, y al que ya nos hemos referido, Tertuliano, Clemente de Alejandría, Orígenes, San Hipólito y San Cipriano, que fueron fundamentales para ello.

La literatura teológica se extendió a casi todas las materias eclesiásticas y entre ellas queremos destacar la teología bíblica que defendieron San Jerónimo, con su Vulgata, San Agustín, San Ambrosio y San Hilario; la moral ascética por San Jerónimo, San Ambrosio, San Agustín y San Casiano y la elocuencia sagrada, por San Ambrosio, San Agustín, San León Magno, San Pedro Crisólogo y Máximo de Aquitania. Por todas estas materias sintió especial interés Cisneros.

Durante los últimos tiempos de la Patrística destacaron entre los escritores griegos, San Juan Damasceno y entre los latinos, además de los citados San Leandro e Isidoro de Sevilla, se hallaban Fulgencio, Boecio y Casiodoro. Todos ellos conservaron el pensamiento y los tesoros literarios de épocas pasadas, cerrando el periodo patrístico San Bernardo.

A todos ellos sumaríamos también el interés de Cisneros, como hemos visto, a través de los libros de su biblioteca, los nombres de Santo Tomás de Aquino, San Vicente Ferrer, Santo Tomás de Cantorbery, San Juan Climaco y Raimundo Lulio y tal vez, los cuatro evangelistas.

Contamos pues con un proyecto iconográfico que intentaríamos reconstruir de la siguiente manera:

1. Albores de la ciencia teológica: Tertuliano, Clemente de Alejandría, Orígenes, San Hipólito.

2. Padres de la iglesia griega: San Atanasio, San Basilio, San Gregorio Nacianeceno, San Juan Crisóstomo.

3. Padres de la Iglesia latina: San Gregorio, San Jerónimo, San Ambrosio, San Agustín.

4. Padres de la Iglesia española: San Ildefonso, San Eugenio, San Isidoro, San Leandro.

5. Literatura teológica: San Hilario, San Casiano, San León Magno, San Pedro Crisólogo.

6. Patrística: Fulgencio, Boecio, Casiodoro.

7. Otros: Santo Tomás de Aquino, San Vicente Ferrer, Santo Tomás de Caterbury, San Raimundo Lulio.

Aunque en el sepulcro del cardenal esculpido por Fancelli, además de los padres de la Iglesia latina y española, se labró en bajorrelieve a las Artes Liberales dentro de hornacinas, pensamos que la idea, que de la Librería tuvo Cisneros, era más propicia a la representación de hombres sabios de Iglesia, que a la representación «profana» de estas artes, pese a que el cardenal sintió especial inclinación por ellas, considerándolas en la línea expuesta por Beauveais en su Espejo de la Ciencia, como alimentadoras del espíritu, haciéndolas corresponder a cada una de ellas con un don del Espíritu Santo ${ }^{30}$. No obstante, muchos de los filósofos y santos que pudieron representarse en la «Librería», por sus quehaceres intelectuales, podrían identificarse, a su vez, con las distintas artes liberales y con filósofos y sabios paganos, por ejemplo Santo Tomás con Aristótoles. Se trataría por ello de un programa de exaltación existencial de la filosofía y teología cristiana a través de sus «hombres sabios», y por tanto, más restrictivo

${ }^{30}$ L. Cheles, The studio of Urbino. An Iconography Investigation, Wiesbaden, 1986.

AEA, LXXVI, 2003, 301, pp. 5 a 21 

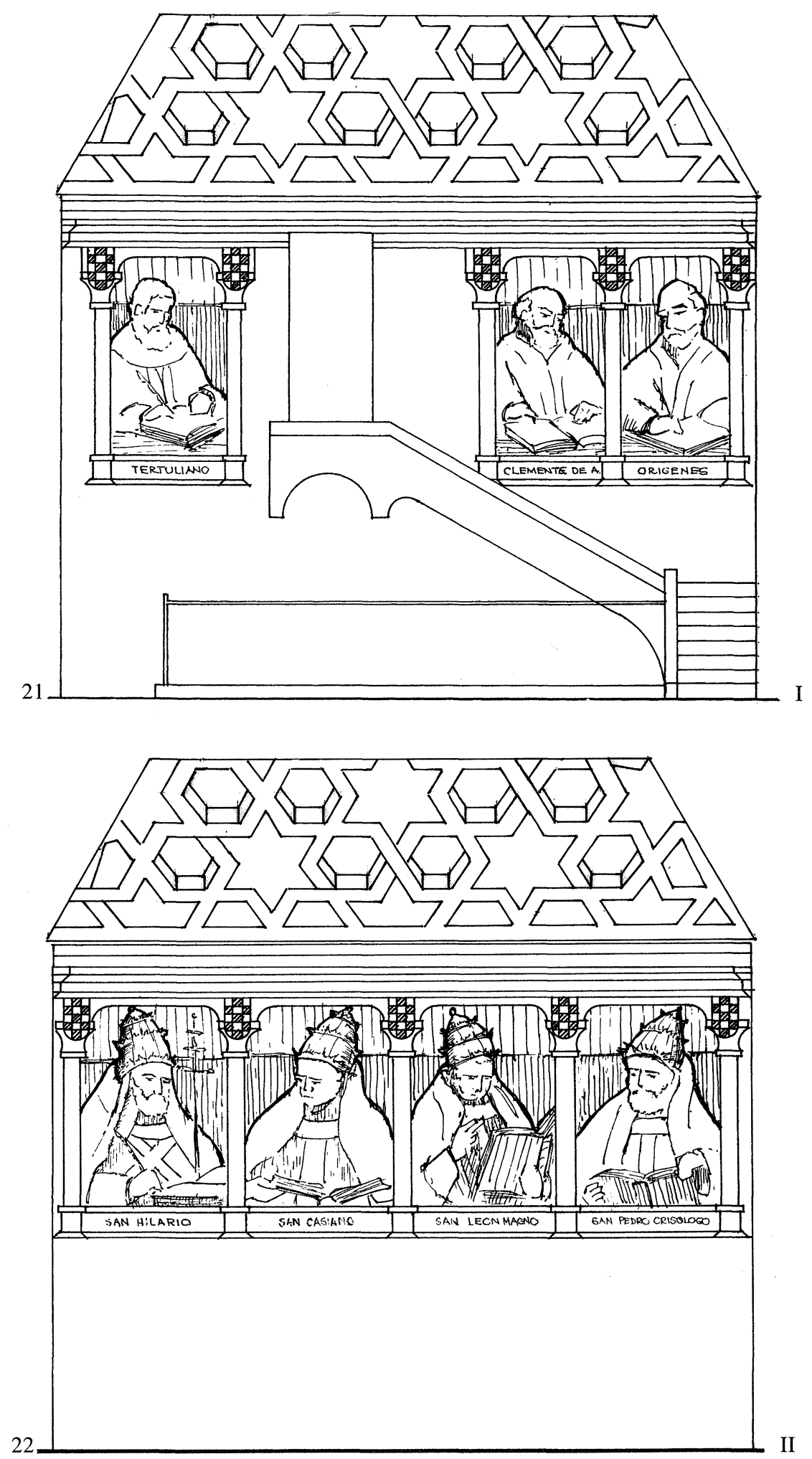

Figs. 20-23. Reconstrucción figurada de las pinturas al fresco con los Padres de la Iglesia y otros «hombres sabios y santos» que pudieron decorar la Librería de Cisneros. Dibujos por Gustavo Márquez. I, muro de la escalera: 7,23 m. Escala 1:60. Figs. 1,60 m.-II, muro frontal: 7,23 m. Escala 1:60. Figs. 1,60 m.

AEA, LXXVI, 2003, 301, pp. 5 a 21 
al sincretismo que presidió el Studiolo de Urbino. Naturalmente en el proyecto de Cisneros podían haber tenido cabida, por su admiración hacia ellos, Aristóteles y Cicerón, y por el contenido moral de sus obras, Dante y Petrarca, pero ellos interrumpirían la estricta presencia de aquellos hombres «santos y sabios» que enriquecieron con sus estudios y escritos el pensamiento de la Iglesia.

Quintanilla, al describir la Librería de Cisneros dice que también estaba «llena de escu$d o s »^{31}$. Esta alternancia de Padres de la Iglesia con los escudos del cardenal nos trae al recuerdo la Capilla del Palacio Arzobispal de Alcalá de Henares, decorada al fresco en tiempos de Fonseca, por Juan Correa de Vivar ${ }^{32}$. En las antiguas fotos que se conservan de estas pinturas, vemos el estado lamentable en que se encontraban, encaladas y picadas parcialmente, pero, todavía se puede apreciar en algunas de ellas lo suficiente, para identificar al pintor, y suponer el programa, con los Padres de la Iglesia representados, al servicio de la misión didáctica de la Iglesia, alternando con los escudos de Fonseca ${ }^{33}$. Juan Correa de Vivar había copiado, casi literalmente, obras del retablo de Ávila, por ello pensamos que muy bien pudo inspirarse para la decoración de esta pequeña capilla en el programa de la Librería, a menor escala (fig. 11). Lo primero que tenemos que resaltar es la presencia de un friso en la parte superior decorado por ángeles tenantes de los escudos de Fonseca y de tarjetones con frases del Credo, alternando con los Evangelistas pintados del tamaño de algo más de medio cuerpo, dentro de hornacinas, y una zona baja sobre un alto zócalo, con los Padres de la Iglesia, también de tres cuartos, pero sentados, sobre un fondo de paisaje y dentro de un óculo. Entre ellos las «santas doctoras», de cuerpo entero y también dentro de hornacinas. La capilla ya estaba en ruinas cuando en 1882 la visita Acosta, lo que hace presumir, por las puertas dieciochescas que aparecen en las fotos, que la destrucción se llevo a cabo en tiempos de Lorenzana. Correa vuelve a representar, a las Santas doctoras, en el retablo para una capilla funeraria, presidido por la tabla de la Imposición de la Casulla a San Ildenfonso, con el retrato de Tavera, sustituyendo el rostro del santo ${ }^{34}$.

Antes de ordenar el programa iconográfico de la Librería debemos tener en cuenta el espacio rectangular de la misma, al que se accede, en la actualidad, desde el Archivo Capitular por medio de una escalera (fig. 12). La Librería ocupa un espacio intermedio entre el piso superior del claustro y la antigua Sala Capitular de verano (figs. 12-13), con la que se comunica por medio de una escalera que es continuación de la primera (figs. 15-17). La Librería se abre a la Chapinería por grandes ventanas y aparece recorrida por armarios, para los libros, diseñados por Gregorio Pardo, según información del canónigo archivero don Ramón Gonzálvez (figs. 12-13). No cabe duda de que estos armarios debieron hacerse como ampliación de los primitivos de Cisneros, de cuya época se conserva el pavimento (fig. 14). Suponemos que el antiguo artesonado que cubría la Librería debía responder a los modelos que Gumiel trazó para la Sala Capitular o para el Paraninfo de Alcalá, cubriéndose en el XVIII por la bóveda de estuco que hoy podemos contemplar apoyada en un entablamento, del mismo estilo, que recorre y corona los espacios blanqueados donde estarían las pinturas ${ }^{35}$.

Teniendo en cuenta los modelos flamencos de Van Eyck, Van der Weyden y Petrus Christus, los «bancos» de retablos pintados por Berruguete, la concepción de los «hombres sabios»

\footnotetext{
${ }^{31}$ Loc. cit., nota 10.

32 I. Mateo Gómez, loc. cit., nota 11.

${ }_{33}$ M. Vega y March, Archivo de Alcalá de Henares. Biblioteca Selecta de Arte Español, vol V.

34 I. Mateo Gómez, loc. cit., nota 11.

35 Se ha pensado que la bóveda actual es la primitiva y que iría decorada en tiempos de Cisneros por pinturas alusivas a la astronomía como la bóveda de la universidad de Salamanca, pintada por Fernando Gallego. Sin embargo teniendo en cuenta el Studiolo, y la obra de Gumiel en la catedral toledana y en Alcalá, nos resulta más lógico pensar en una cubierta de artesonado, recubierta en la actualidad por la bóveda rebajada de yeso del xviII. Sería interesante hacer una cala de la misma para confirmarlo y otra en las paredes encaladas, para ver lo que pueda conservarse de las pinturas.
}

AEA, LXXVI, 2003, 301, pp. 5 a 21 


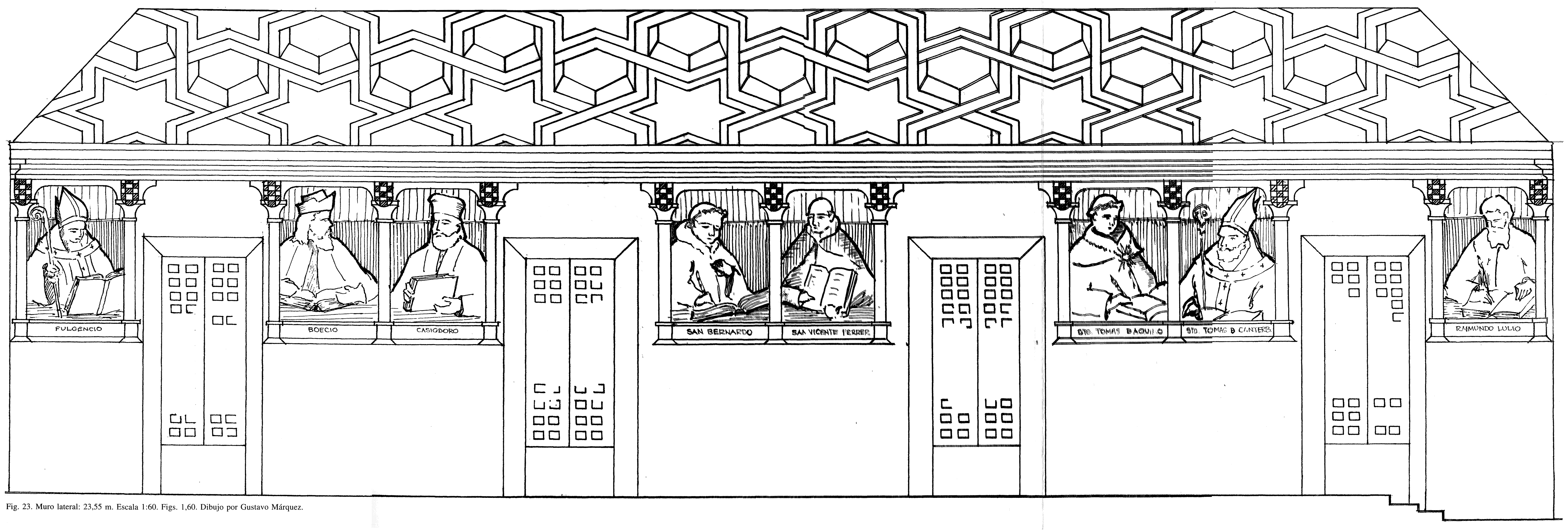


del Studiolo de Urbino, el formato de los arzobispos de la Sala Capitular toledana y los del Palacio Arzobispal de Alcalá de Henares (figs. 1-11), pensamos que los Padres de la Iglesia que decoraban la Librería, eran del tamaño de tres cuartos, pintados aisladamente pero emparejados dentro de columnas o pilastras, sobre cuyas zapatas iría el escudo de Cisneros como remate. El fondo de cada uno de ellos podría ser el de una «habitación» como en Urbino, o el de un paisaje, en ambos casos para dar profundidad al espacio pintado (figs. 21-23).

No vamos a repetir aquí las medidas que aparecen en los dibujos y trazas que adjuntamos, solo advertiremos, que teniendo en cuenta el largo y ancho de las paredes de la actual Librería, y las dimensiones de los «hombres sabios» de Urbino, tienen cabida en el espacio toledano los iniciadores en la Ciencia teológica; los Padres de la Iglesia griega, latina y española; los representantes de la literatura teológica y Patrística y, finalmente, aquellos santos que, por sus escritos, tuvieron la consideración de «hombres sabios» por Cisneros, en el programa de humanismo cristiano que decoró la magnífica librería proyectada el cardenal y, seguramente trazada por Pedro Berruguete y ejecutada después por Juan de Borgoña y Pedro Gumiel, cuando el cardenal ya no la pudo disfrutar.

* Después de escrito este artículo, ha aparecido el de F. Marías y F. Pereda: «Petrus Hispanus en Urbino y el bastón del Gonjaloniere: el problema Pedro Berruguete en Italia y la historiografía española», Archivo Español de Arte, 2002, oct.dic., pp. 361-380. En este trabajo se pone en duda la estancia de Berruguete en Toledo anterior al año 1488, y cual fue su relación con la catedral. También queremos hacer mención de la exhaustiva y clarificadora ficha que sobre las pinturas del Studiolo de Urbino y la intervención en ellas de Pedro Berruguete, ha aparecido en el reciente Catalogue de Ecoles espagnole et portugaise, del Museo del Louvre, debidas aVeronique Gerard Powell y Claudie Ressort. París, 2002, págs. 42-71. Agradezco al Archivo Capitular de la catedral toledana la ayuda que me ha prestado a lo largo de este trabajo. 